\title{
Kit Dosing Unit
}

National Cancer Institute

\section{Source}

National Cancer Institute. Kit Dosing Unit. NCI Thesaurus. Code C48504.

A dosing unit equal to the amount of active ing redient(s) contained in a kit. 